\title{
A Model for Improving Knowledge Generation in Design Science Research through Reflective Practice
}

\author{
J.T. Janse van Rensburg ${ }^{1}$ and Roelien Goede ${ }^{2}$ \\ ${ }^{1}$ North-West University, Vanderbijlpark, South Africa \\ ${ }^{2}$ North-West University, Potchefstroom, South Africa \\ jt.jansevanrensburg@nwu.ac.za \\ roelien.goede@nwu.ac.za \\ DOI: 10.34190/ JBRM.17.4.001
}

\begin{abstract}
Epistemology refers to the philosophy of knowledge and aims to address central questions of how we create new knowledge. All research paradigms can be distinguished in terms of epistemological assumptions, that is, assumptions of how knowledge is produced in the respective paradigms. Design science research (DSR) is a research paradigm often used in technical disciplines for the creation of artefacts. DSR has roots in pragmatism, where beliefs and theories are evaluated based on the success of its practical application. New knowledge is produced in DSR when original artefacts are created to solve a problem. The epistemological assumption of DSR can then shortly be defined as 'knowledge through making'. At its core, DSR is goal-orientated and its practical approaches are focused on delivering the product according to straightforward processes - without being affected by human factors. This process of acquiring new knowledge is efficient but not necessarily effective in terms of capturing all aspects of the experience of the practitioner. Frameworks exist for the creation of artefacts in DSR, but the process of knowledge generation is not explicit. The aim of the paper is to guide explicit knowledge generation in DSR. The research question is "How can we make the process of obtaining knowledge in DSR more explicit?" DSR Frameworks are iterative in nature and focus on the creation and evaluation of artefacts. There is an implicit assumption that reflection takes place in these iterations. Schön, author of The Reflective Practitioner, writes that new knowledge is produced through reflection during and after an event has occurred. He also states that you can only have a complete understanding of a problem through the dual process of reflection-in-action and reflection-on-action. We argue that this also holds true for artefact design and development in DSR. A reflective DSR practitioner can explicitly indicate how knowledge is produced in the design science research cycle. The effective use of reflective practice changes each individual phase of a DSR framework from goal-orientated to problem-orientated. Epistemologically, knowledge is then produced through 'learning by doing', which gives DSR a worldview that supports reflective practice. The paper promotes the incorporation of reflective practice in DSR and provides a demonstration thereof in an example on the preparation of IT students for their chosen career.
\end{abstract}

Keywords: Design science research, reflective practice, epistemology, knowledge generation

\section{An introduction to the epistemological assumptions of design science research}

All paradigms have ontological, epistemological and axial assumptions which guide the research process (Vaishnavi \& Kuechler, 2004; Oates, 2006; Scotland, 2012). Even though these terms motivate assumptions about reality, knowledge and value for any intellectual effort, they are implicit for most people, including researchers (Vaishnavi, Kuechler \& Petter, 2017). Researchers may conduct investigations for the duration of their professional careers without realising the philosophical implications of their research approaches (Kuhn, 1996). One of these terms, epistemology, refers to the theory of knowledge and is concerned with understanding the limitations, the validity and the scope of knowledge (Myers, 2009). An epistemological assumption is concerned with exploring the creation of knowledge and the manner in which individuals learn about their supposed reality i.e. what does knowledge depend on, how can we be sure that what we know is correct. Epistemology explains how knowledge is created, how knowledge is attained, how knowledge is articulated and how knowledge is communicated (Scotland, 2012).

In design science research (DSR), new knowledge is created by designing innovative artefacts as a solution to a relevant human problem (Hevner \& Chatterjee, 2010). Vaishnavi and Kuechler (2004) support this definition by stating that DSR alters the world through the creation of innovative artefacts. An artefact can include, but is not limited to, constructs, models, methods, and instantiations (March \& Smith, 1995), as well as frameworks, architectures, design principles and design theories (Purao, 2002; March \& Smith, 1995; Gregor \& Jones, 2007; Gregor \& Hevner, 2013).

In DSR, a piece of information is factual and the meaning of the information is made clear through circumscription. An artefact is developed, and the interaction between its components results in its behaviour. 
Descriptions of these interactions become information, and the level to which the behaviour is predictable makes the information factual. DSR is dependent on an artefact that functions in a predictable manner. The functionality the artefact delivers comprises of what the meaning of the artefact is - which supports the epistemological stance of 'knowing through making' (Vaishnavi et al, 2017). The theoretical standpoint of DSR may change as it iterates through phases of artefact development, changing from a positivist whilst recording behaviour, to an action researcher when interpreting the observations and planning subsequent interventions.

DSR practitioners have more success when they move between pragmatic and critical realist standpoints, directed by a pragmatic evaluation of development in the DSR cycle (Bunge, 1984). "The design science researcher arrives at an interpretation (understanding) of the phenomenon and the design of the artefact simultaneously" (Purao, 2013).

The aim of design science research then is to contribute new design science knowledge that is "a body of intellectually tough, analytic, partly formalizable, partly empirical teachable doctrine about the design process" (Simon, 1996). The design science researcher can then be seen as a pragmatist (Peirce, 1931).

\section{Design science research process}

This section provides an overview on the role of knowledge in DSR and how knowledge is generated.

\subsection{Role of knowledge}

"Knowledge is generated and accumulated through action. Doing something and judging the results is the general model... the process is shown as a cycle in which knowledge is used to construct works, and works are evaluated to build knowledge" (Owen, 1997). A graphical representation of this can be seen in Figure 1. The process to build knowledge through creation is not unstructured, although sometimes thought to lack rigour (Vaishnavi et al, 2017). The channels in the diagram below are the "systems of conventions and rules under which the discipline operates. They embody the measures and values that have been empirically developed as "ways of knowing" as the discipline has matured. They may borrow from or emulate aspects of other disciplines' channels, but, in the end, they are special to the discipline and are products of its evolution" (Owen, 1997). In short, the creation of artefacts produces new knowledge as part of the knowledge building process. Researchers then delve into the knowledge base to inform designs of new artefacts. This then becomes an iterative process where knowledge is added to the knowledge base through creation, and improved artefacts are created due to the existing knowledge base.

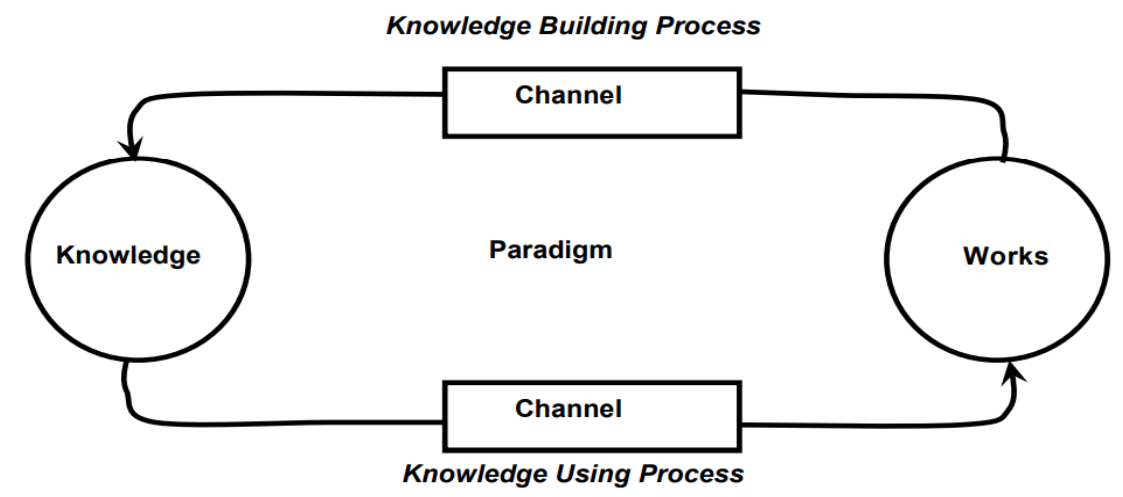

Figure 1: A general model for generating and accumulating knowledge (Owen, 1997)

Different types of contributions can be made to the knowledge base of design science research. Levels of abstraction are explained where contributions to DSR can start with the creation of artefacts, evolve into design principles for artefacts and further be defined into design theories (Purao, 2002).

Design science research is categorised into two groups of knowledge, descriptive and prescriptive knowledge. Descriptive knowledge (omega knowledge) is concerned with the 'what' and prescriptive knowledge (lambda knowledge) is concerned with the 'how' knowledge of created artefacts (Gregor \& Hevner, 2013). Examples of descriptive knowledge include phenomena (such as observations, measurements and classifications) and sense-making (principles, theories, patterns etc.) Examples of prescriptive knowledge include artefact creation such as constructs, models, methods, instantiations and design theory. 


\subsection{Knowledge generation}

Within the context of DSR there are different research approaches available. Vaishnavi and Kuechler (2017) established an original framework for design science research in 2004, which was later adopted by Hevner and Chatterjee (2010) (Figure 2). The framework was an adaptation of the model for a computable design process (Takeda, 1990). The phases in the design process and the design science research are similar, but the activities that take place in each phase are significantly different. The biggest difference is that the DSR process requires that the contribution of new knowledge be a key focus of its approach. This framework is still applicable in their latest research. The DSR framework iterates through five phases. The researcher first becomes aware of a problem, suggests a possible solution to the problem, the suggested solution is then developed and evaluated until the research process can naturally conclude. The DSR framework is goal-orientated. Knowledge is generated through circumscription of the process followed to reach the conclusion. This contribution of knowledge is known as Design Science Knowledge. Notably, Peffers, Tuunanen, Rothenberger, and Chatterjee (2008) also created a model for DSR called the DSRM (design science research methodology) model. Peffers et al (2008) appear to present this model as an evolved version of the DSR framework by Vaishnavi and Kuechler (2004) by iterating through six clearly defined phases that follow the same logical flow of events. When comparing the DSR framework and the DSRM model, both approaches suggest that reflection and abstraction take place in their final phases only.

Knowledge is explicitly generated during the last phase of the DSRM model, by suggesting that the results should be communicated through scholarly and professional publications.

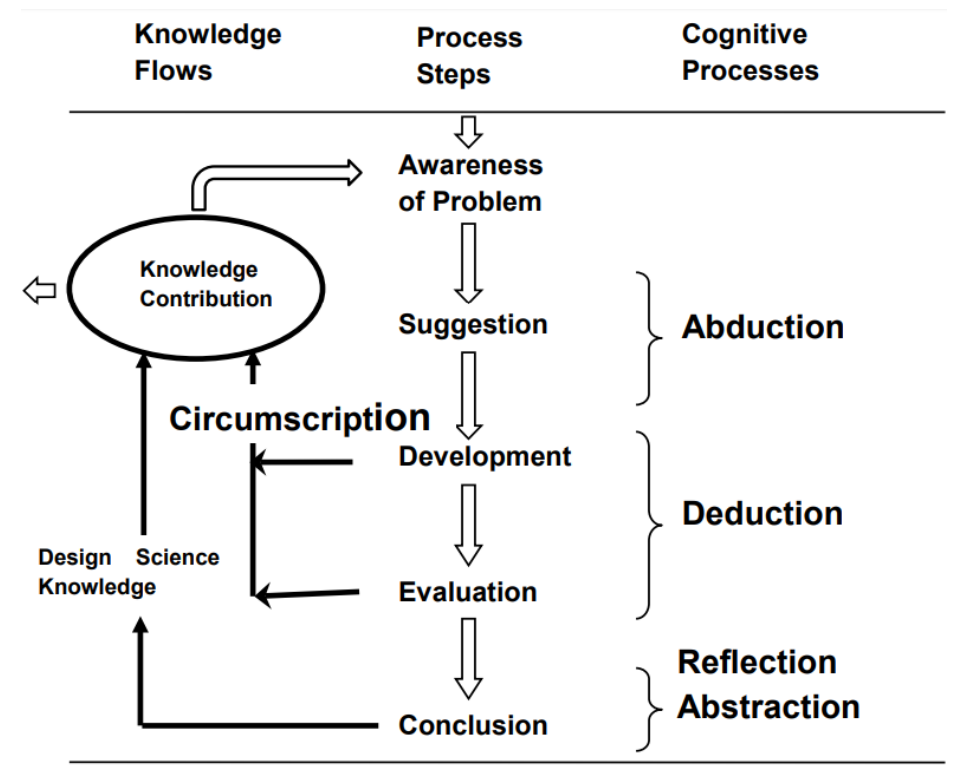

Figure 2: Cognition in the DSR framework (Vaishnavi et al, 2017)

There is an implicit assumption that reflection takes place in both approaches. The presentation of the models however, only explicitly suggests that reflection takes place in the last phases when the project is concluded and communicated. The cycle for cognition in DSR (Figure 2) illustrates the cognitive process followed by indicating the type of knowledge that is produced in each phase of the DSR framework. The DSR framework goes through cycles of abduction, deduction, abstraction and reflection. The creative intellectual process of reflection is used in the conclusion phase to contribute to design science knowledge. In the DSR framework, the overall contribution to advance knowledge needs to be argued at the conclusion of the project (Vaishnavi et al, 2017).

\subsection{Limitations in DSR knowledge generation}

The aim of the paper is to report on how the process of knowledge generation could be made more explicit if reflective practice is applied throughout the framework, and not only when concluding a project as suggested in Figure 2. The premise of the research implies that there are limitations in the knowledge generation process of the design science research framework. 
Knowledge generation in DSR is not explicit. DSR frameworks are iterative in nature and focus on the creation and evaluation of artefacts. Knowledge generation is a result of circumscription of the process followed. The contribution of the knowledge then adds to the knowledge base of design science knowledge. There is an implicit assumption that reflection takes place in these iterations but it is only explicitly stated as part of the conclusion phases of the approaches.

A body of knowledge already exists on the foundation of learning by doing. The epistemological assumption of DSR which is "knowing through making" is limited when compared to the epistemological assumption of reflective practice which is "learning by doing". Even in scientific professions, when practitioners address unique problems, it is an artistic process in which reflective practice takes place (Schön, 1983). Reflective practice is a professional learning and development strategy focused on improved practices, based on assumptions that cause-effect relationships shape behaviour (Osterman, 1998).

Reflective practice is a continuous process. Building on the first limitation listed, the DSR framework only explicitly states that reflection/ abstraction takes place when the cycle has concluded. Reflective practice is intuitively similar to DSR but incorporates known scientific methods for explicitly stating how knowledge is generated. Using reflective practice should be a continuous process throughout the phases of the DSR framework and should not be limited to the conclusion of the artefact.

A model formulated for the use of explicit knowledge generation in design science research would thus require continuous integration of reflective practice approaches embedded in its iterative phases.

\section{Explicit knowledge generation in reflective practice}

This section provides a shared understanding of reflective practice, and the known scientific methods for knowledge generation within its process.

Reflection is an action of self-deliberation that involves using prior experience and contextual awareness. It is an essential skill that enables one to formulate a philosophy of sharing knowledge and can be used as a standard to observe and measure other professionals' practices (Atkinson \& Irving 2013). Reflective practice comprises carefully considering our personal experiences when knowledge is applied to practice (Schön, 1983).

A reflective practitioner should continuously reflect on his or her experiences and draw knowledge from these practices. Reflective practice is the dual process of immediate reflection during a situation (reflection-inaction) and also reflecting on the situation after it has been resolved in order to better resolve similar scenarios in the future (reflection-on-action) (Schön, 1983). Reflective practice has been defined by numerous academics as the process of learning from and through one's experiences with the aim of acquiring a new understanding of practice ((Boud et al, 1985; Boyd \& Fales, 1983; Mezirow, 1981, Jarvis, 1992)). The academic evolution of reflective practice has produced a number of explicitly stated processes for knowledge generation.

Reflective practice is rooted in experiential learning, where the process of learning is most effective when it starts with a problematic experience. The four stages of learning according to Kolb (1984) gives experiential learning as a cyclical process that starts with an experience, continues with reflective observation, leads to an abstract conceptualisation of the problem and results in active experimentation to address the problem. The last stage may result in a different experience which prompts the continuation of reflective observation and so on (Figure 3). 
for theory building and through the use of reflective practice the knowledge generated could contribute to the prescriptive knowledge of DSR.

To summarise, the following advantages of using reflective practice for improved knowledge generation in design science research are noted:

- Knowledge generation in reflective practice is explicit.

- Knowledge generation in reflective practice fits into known scientific methods.

- Knowledge generation in reflective practice is intuitively similar to that of design science research when following a cyclical model for creating ideas.

- Knowledge generation through reflective practice puts a stronger focus on the creation of prescriptive knowledge in design science research.

From the perspective of reflective practice, a model for explicit knowledge generation in DSR should include:

- Engaging in reflective practice to gain a deeper understanding of the problem experienced.

- Reflection that takes place during each phase of the DSR framework while iterating through the phases.

- Reflection that takes place after each phase of the DSR framework has been completed to better improve future similar scenarios.

- Reflection that takes place in context of observation and abstraction during each phase of the framework with the aim of understanding which type of knowledge was generated.

- Embedding continuous reflection to deliver explicit DSR knowledge during active experimentation of suggestions made toward addressing the problem experienced.

The next section provides an overview of how these advantages, and suggested elements for a DSR model that produces explicit knowledge generation, motivate the use of reflective practice to enrich design science research knowledge generation.

\section{Improving knowledge generation in DSR through reflective practice}

New knowledge in DSR is produced through the process of creation. The creation of artefacts is a practical approach to knowledge building. The practical nature of DSR has roots in pragmatism, where approaches and theories are evaluated based on their practical application. DSR and pragmatism both lend toward goalorientated approaches, which is why knowledge generation through reflection typically only takes place when the project has concluded. This process of acquiring new knowledge is efficient but not necessarily effective in terms of capturing all aspects of the experience of the practitioner.

For example, the DSR framework iterates through five phases, the first of which is becoming aware of a problem. An individual wishing to do research on a specific problem area has already employed some form of reflective practice by researching a phenomenon that cannot be addressed by tacit knowledge or knowing-inaction. During the suggestion phase the researcher could offer a solution from his existing knowledge but it would be better practice to include other researchers to jointly reflect on possible solutions for the problem.

During the development phase the research will reflect on the initial design of the artefact and choose to conduct evaluation methods to better understand the context of the artefact. During the evaluation phase the researcher will include users or experts to assess the artefact. This is a deeply reflective practice as the feedback obtained creates a richer picture of the solution than the researcher could have suggested on his own. During the conclusion phase the researcher reflects on the methods he used and determines whether the artefact is an appropriate solution to the original problem. He also determines whether new problems may arise which may need suggested solutions and so on. This also is a deeply reflective practice as the researcher cannot conclude the study if he believes that other researchers will not accept the results. The DSR framework in its entirety can then be seen as following a process of reflective practice, even though researchers only propose reflection in its conclusion phase (Vaishnavi et al, 2017).

A reflective DSR practitioner has the ability to explicitly indicate how knowledge is produced in the design science research cycle. The effective use of reflective practice changes each individual phase of a DSR framework from goal-orientated to problem-orientated. Epistemologically, knowledge is then produced through 'learning by doing', which gives DSR a worldview that supports reflective practice. Reflective practice 
focuses on the user's ability to reflect on situations as they occur but also after they have occurred to improve future practices.

Within the context of design science research, reflective practice is a valuable approach for knowledge generation in a project. The reflective practice process of experiential learning can be used in the DSR framework for improved knowledge generation. The DSR framework is iterative in nature and can move forwards or backwards in any of its phases. It can then be suggested that the cycle of experiential learning should take place during phases to promote abstraction and explicit knowledge generation. Furthermore, the process of moving forward in the DSR framework is typically when reflection-in-action takes place e.g. 'What do I currently need to move forward to the next phase?' The process of moving backwards in the DSR framework is when reflection-on-action takes place e.g. 'How can I improve future iterations under similar circumstances?' Figure 5 provides a graphical representation of a DSR framework enriched with reflective practice for improved knowledge generation.

\section{A Reflective Practice DSR framework model}

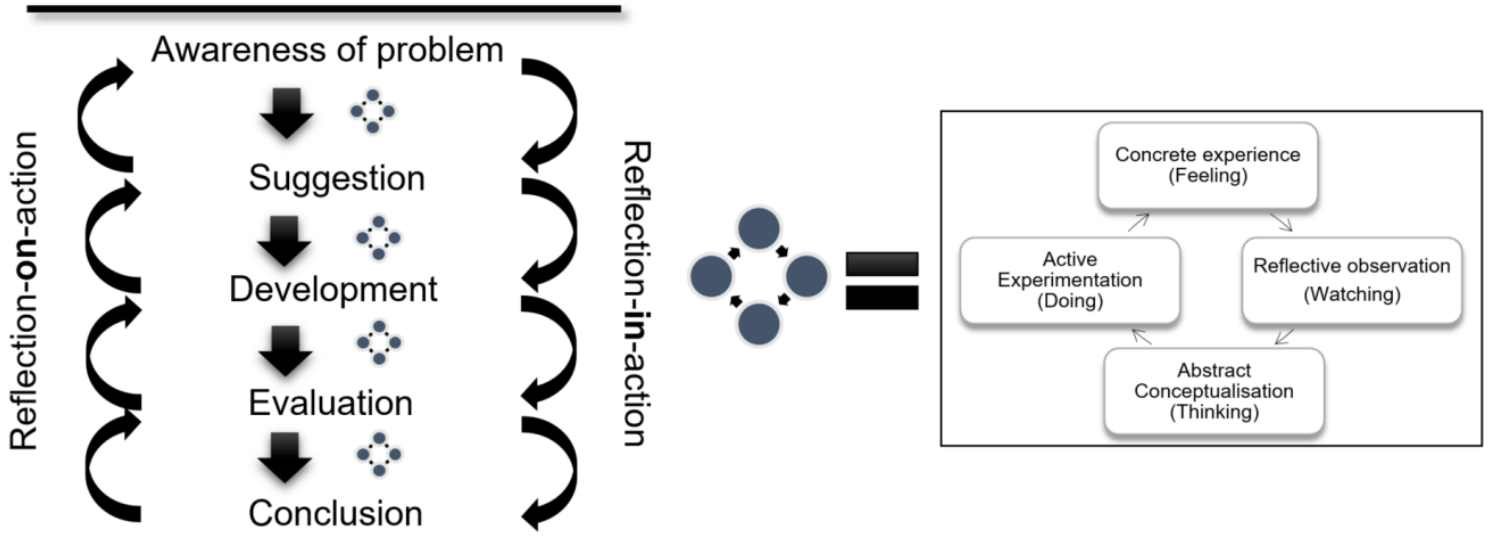

Figure 5: A reflective practice DSR framework model

The use of the DSR framework enriched with reflective practice can be used to explicitly indicate knowledge generated for all types of artefacts. As depicted in Figure 5, the reflective practice cycle is incorporated in each phase of the DSR framework, allowing a reflective process of abstraction to take place for knowledge generation before continuing to the next phase. This method of reflective practice provides a scientific approach for knowledge generation throughout the DSR framework, and not only when concluding a developed artefact as depicted in Figure 2. To further explain the process of embedding reflective practice in the DSR framework, Table 1 provides an in-depth overview of how experiential learning can generate explicit DSR knowledge.

Table 1: An overview of how reflective practice can generate explicit knowledge in the DSR framework

\begin{tabular}{|c|c|c|c|}
\hline 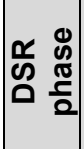 & $\begin{array}{l}\frac{0}{0} \\
\frac{\pi}{0} \\
0 \\
\alpha\end{array}$ & $\begin{array}{l}\text { Addressing a problem experienced in related fields to higher education, } \\
\text { information technology and engineering }\end{array}$ & $\begin{array}{c}\text { Explicit } \\
\text { knowledge } \\
\text { generation }\end{array}$ \\
\hline 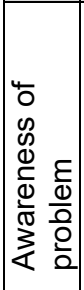 & 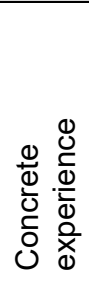 & $\begin{array}{l}\text { A specific problem is experienced in a specific context, for example, information } \\
\text { technology, engineering or higher education (amongst others). } \\
\text { There is a desire for change to improve the problem experienced. } \\
\text { The problem experienced is currently relevant, and when researched indicate } \\
\text { existing gaps in the literature that require further development. } \\
\text { A critical reflection and analysis of the problem in context is required before } \\
\text { attempting to suggest solutions. }\end{array}$ & $\begin{array}{l}\text { Strategies are } \\
\text { researched } \\
\text { and } \\
\text { evaluated for } \\
\text { its } \\
\text { appropriatene } \\
\text { ss in } \\
\text { addressing }\end{array}$ \\
\hline
\end{tabular}




\begin{tabular}{|c|c|c|c|}
\hline 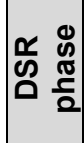 & $\begin{array}{l}\frac{0}{0} \\
\frac{0}{0} \\
0\end{array}$ & $\begin{array}{c}\text { Addressing a problem experienced in related fields to higher education, } \\
\text { information technology and engineering }\end{array}$ & $\begin{array}{c}\text { Explicit } \\
\text { knowledge } \\
\text { generation }\end{array}$ \\
\hline & 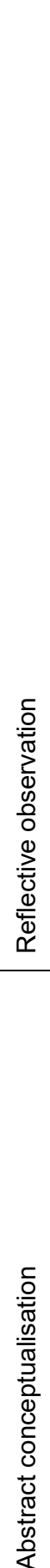 & 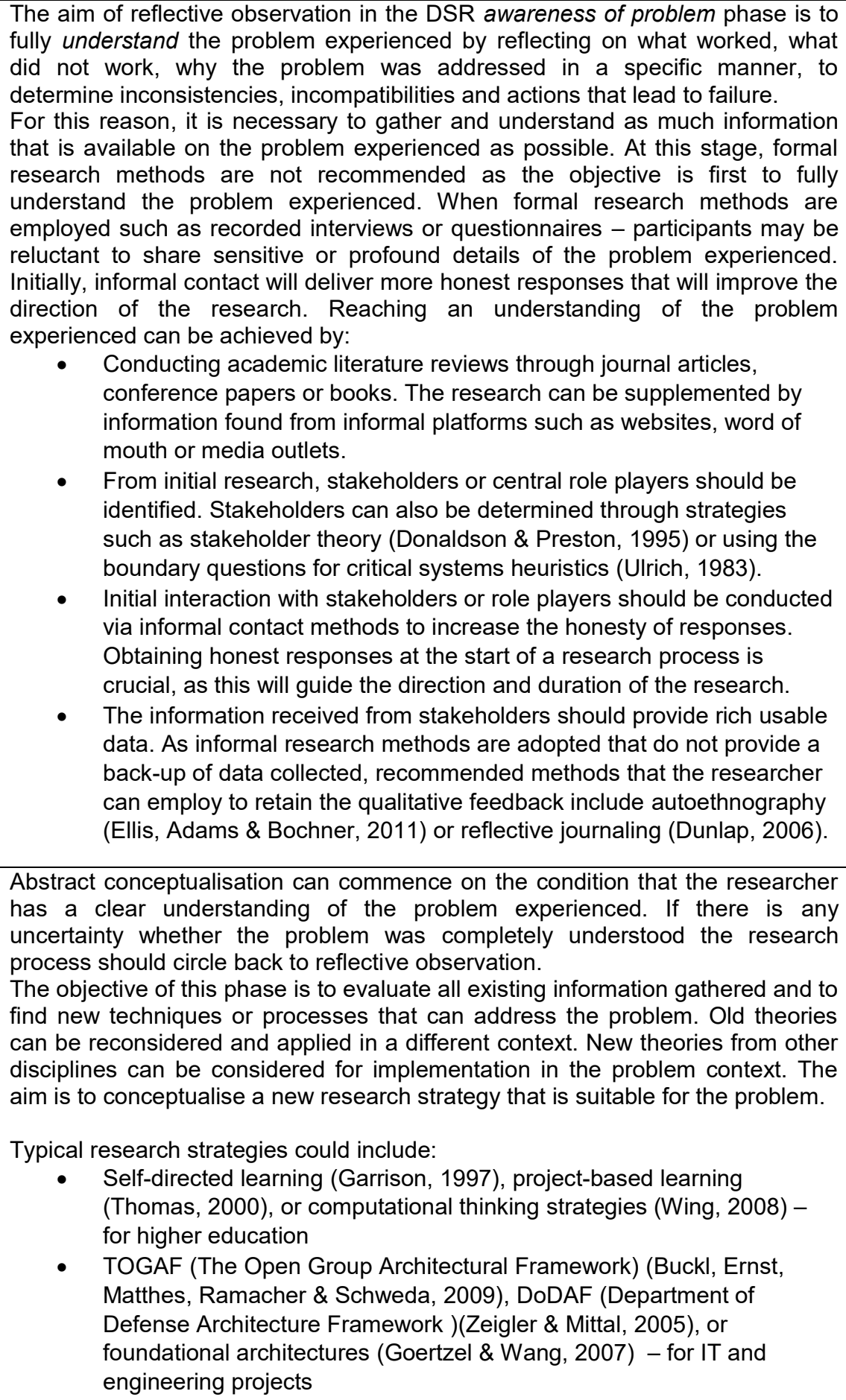 & $\begin{array}{l}\text { the problem. } \\
\text { Explicit } \\
\text { knowledge is } \\
\text { generated in } \\
\text { the form of } \\
\text { proposed } \\
\text { strategies } \\
\text { that could suit } \\
\text { a specific } \\
\text { problem. }\end{array}$ \\
\hline
\end{tabular}




\begin{tabular}{|c|c|c|c|}
\hline 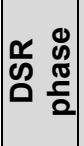 & $\begin{array}{l}\frac{0}{0} \\
\frac{0}{0} \\
0 \\
\alpha\end{array}$ & $\begin{array}{l}\text { Addressing a problem experienced in related fields to higher education, } \\
\text { information technology and engineering }\end{array}$ & $\begin{array}{c}\text { Explicit } \\
\text { knowledge } \\
\text { generation }\end{array}$ \\
\hline & 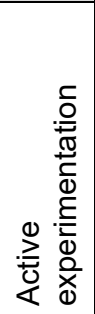 & $\begin{array}{l}\text { The identified research strategies should be informally discussed with the } \\
\text { stakeholders. Suggesting suitable research strategies that are accepted by the } \\
\text { stakeholders indicate that the researcher has a clear understanding of the } \\
\text { problem. } \\
\text { Reactions and behaviours should be observed when the research strategies are } \\
\text { suggested. If all stakeholders do not agree with the suggested research } \\
\text { strategies, it implies that the problem was not completely understood and this } \\
\text { will lead to refined theories and approaches. }\end{array}$ & \\
\hline \multirow[b]{4}{*}{ 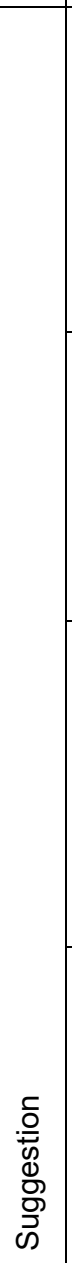 } & 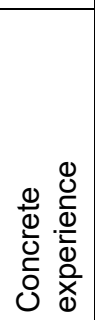 & $\begin{array}{l}\text { The suggestion phase of the DSR framework can only commence when } \\
\text { suggested research strategies resulted in a positive experience for the } \\
\text { stakeholders. A negative experience indicates that the problem was not } \\
\text { completely understood and that the research process should circle back to the } \\
\text { awareness of problem DSR phase. } \\
\text { Identified research strategies can then be further researched for their possible } \\
\text { effectiveness in solving the problem. The suggested research strategies should } \\
\text { explicitly bring about change to the problem experienced. }\end{array}$ & \multirow{4}{*}{$\begin{array}{c}\text { Gaps in } \\
\text { literature are } \\
\text { identified. } \\
\text { New } \\
\text { information is } \\
\text { added to the } \\
\text { knowledge } \\
\text { base in order } \\
\text { to address } \\
\text { the gap. }\end{array}$} \\
\hline & 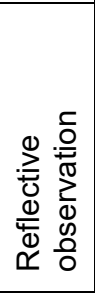 & $\begin{array}{l}\text { The objective of reflective observation in the suggestion phase is to promote a } \\
\text { deeper understanding through research of the strategies or approaches that } \\
\text { were well received by the stakeholders. } \\
\text { Once the researcher has achieved a deeper understanding, the stakeholders } \\
\text { are informally updated on new information regarding suitable strategies and } \\
\text { approaches that were suggested. Stakeholders should actively be informed of } \\
\text { new developments to ensure that the identified research is still addressing the } \\
\text { problem experienced and does not stray from the initial issue. }\end{array}$ & \\
\hline & 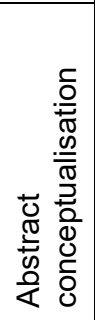 & $\begin{array}{l}\text { Abstract conceptualisation in the suggestion DSR phase aims to consolidate } \\
\text { information gathered from academic research with informal discussions or } \\
\text { conversations held with stakeholders. This action should lead to identifiable } \\
\text { gaps in the research that emphasise the possibility of new suitable approaches } \\
\text { toward addressing the problem experienced. } \\
\text { When identifying appropriate strategies or approaches to address that gap in } \\
\text { research, it is important to reflect on how, and which type of, knowledge will be } \\
\text { generated when these methods are implemented. }\end{array}$ & \\
\hline & 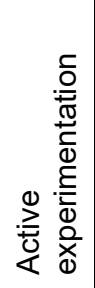 & $\begin{array}{l}\text { During active experimentation in the suggestion DSR phase, new strategies and } \\
\text { approaches identified to address the gap should be presented to the } \\
\text { stakeholders during informal discussions. The suitability of the new approaches } \\
\text { will rely largely on acceptance from the stakeholders. } \\
\text { Strategies or approaches that are questionable need further research and } \\
\text { development, and the research process may need to circle back to reflective } \\
\text { observation for refinement. }\end{array}$ & \\
\hline 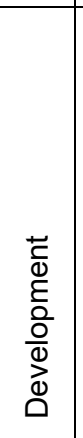 & 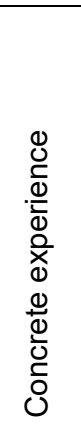 & $\begin{array}{l}\text { A concrete positive experience results from the suggested new strategies and } \\
\text { approaches. A feasible suggestion is agreed upon by all stakeholders for } \\
\text { implementation toward solving the problem experienced. } \\
\text { A needs analysis or requirements analysis (Potts, Takahashi \& Anton, 1994) } \\
\text { may be required before development of the strategy can commence in order to } \\
\text { fully comprehend how the suggested strategy will address the problem } \\
\text { experienced. } \\
\text { The development phase can be guided by methods used for implementation } \\
\text { which can be extended to suit the context of a problem experienced in higher } \\
\text { education, IT or engineering such as design thinking (Brown \& Wyatt, 2010), } \\
\text { prototyping (Zalzal, Gava, Kelouwani \& Cohen, 2009), or agile methodologies } \\
\text { (Maruping, Venkatesh \& Agarwal, 2009). }\end{array}$ & $\begin{array}{l}\text { Specific } \\
\text { strategies are } \\
\text { adopted for } \\
\text { the problem } \\
\text { experienced } \\
\text { based on } \\
\text { research and } \\
\text { feedback. } \\
\text { Formal } \\
\text { research } \\
\text { methods are } \\
\text { employed }\end{array}$ \\
\hline
\end{tabular}




\begin{tabular}{|c|c|c|c|}
\hline 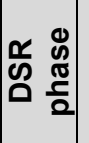 & $\begin{array}{l}\frac{0}{0} \\
\frac{ত}{0} \\
0 \\
\frac{1}{\alpha}\end{array}$ & $\begin{array}{c}\text { Addressing a problem experienced in related fields to higher education, } \\
\text { information technology and engineering }\end{array}$ & $\begin{array}{c}\text { Explicit } \\
\text { knowledge } \\
\text { generation }\end{array}$ \\
\hline & 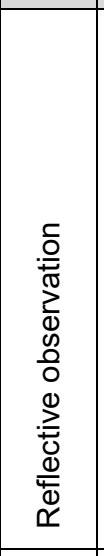 & $\begin{array}{l}\text { The development of the strategy in context of the problem experienced has } \\
\text { commenced. Continuous feedback is required from stakeholders to ensure that } \\
\text { the development of the suggested strategy remains relevant to the problem } \\
\text { experienced. } \\
\text { At this stage of the research it is recommended to start using formal research } \\
\text { methods for data gathering and analysis such as interviews and questionnaires } \\
\text { (Zhang, Kuchinke, Woud, Velten, \& Margraf, 2017), or participatory design } \\
\text { (Bratteteig \& Wagner, 2016). } \\
\text { The qualitative feedback received from stakeholders should provide rich usable } \\
\text { data. Scientific guidelines for data analysis can be followed to improve the } \\
\text { integrity of the findings. Example approaches for data validation include the } \\
\text { principles for conducting and evaluating interpretive field studies in information } \\
\text { systems (Klein \& Myers, 1999) and the qualitative analysis of content (Zhang \& } \\
\text { Wildemuth, 2009). Tools for qualitative data analysis may include traditional } \\
\text { spreadsheets or advanced software such as Atlas.ti. }\end{array}$ & \multirow[t]{3}{*}{$\begin{array}{l}\text { that deliver } \\
\text { scientific } \\
\text { findings } \\
\text { which add } \\
\text { value to the } \\
\text { knowledge } \\
\text { base. } \\
\text { Limitations to } \\
\text { chosen } \\
\text { strategies are } \\
\text { identified. } \\
\text { Suggestions } \\
\text { to address } \\
\text { the limitations } \\
\text { are } \\
\text { presented. }\end{array}$} \\
\hline \multirow[t]{2}{*}{ 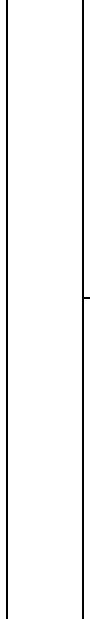 } & 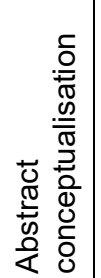 & $\begin{array}{l}\text { Formal qualitative data analysis methods will deliver scientific findings that can } \\
\text { inform the development of the strategy at an academic level. } \\
\text { Research remains a continuous process, and as the data analysis provides } \\
\text { insights into the development of the strategy, new knowledge is generated and } \\
\text { added to the knowledge base. } \\
\text { Formal research is produced, and can be consolidated with existing strategies } \\
\text { to further refine the research process and suggested approaches. }\end{array}$ & \\
\hline & 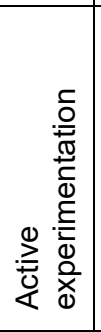 & $\begin{array}{l}\text { During the development of the strategy, challenges will occur. Stakeholders may } \\
\text { react differently than expected, and behaviours should be observed to } \\
\text { understand the context of the concerns identified. } \\
\text { Challenges result in new experiences that guide the research process and } \\
\text { determines which actions should be taken. } \\
\text { lterative development is emphasised for improved outcomes as learning is a } \\
\text { continuous process. If the initial strategy fails, the feedback from stakeholders } \\
\text { leads to refined theory. If the developed strategy is considered acceptable, the } \\
\text { research process continues to evaluation. }\end{array}$ & \\
\hline \multirow[b]{3}{*}{ 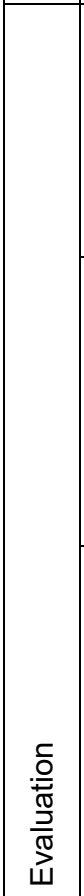 } & 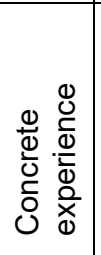 & $\begin{array}{l}\text { Depending on the type of experience that resulted from the previous DSR } \\
\text { phase, the developed strategy is subject to evaluation. Evaluation will highlight } \\
\text { additional shortcomings not identified through data analysis. } \\
\text { In context of higher education, IT or engineering, evaluation may include formal } \\
\text { research methods such as TAM (Technology Acceptance Model) (Legir, Ingham } \\
\text { \& Collerette, 2003), UX (user experience) evaluation (Law \& Abrahão, 2014), or } \\
\text { extending traditional data gathering methods that include stakeholder feedback. }\end{array}$ & \multirow{3}{*}{$\begin{array}{l}\text { Different } \\
\text { evaluation } \\
\text { methods are } \\
\text { researched } \\
\text { that will } \\
\text { deliver the } \\
\text { best possible } \\
\text { feedback for } \\
\text { the strategy } \\
\text { developed. } \\
\text { Evaluation of } \\
\text { the strategy } \\
\text { contributes } \\
\text { knowledge on } \\
\text { successful } \\
\text { and } \\
\text { unsuccessful } \\
\text { approaches. } \\
\text { Academic } \\
\text { literature is } \\
\text { added to the } \\
\text { knowledge } \\
\text { base. }\end{array}$} \\
\hline & 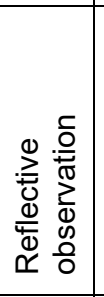 & $\begin{array}{l}\text { In the evaluation phase, reflective observation refers to the researcher's ability } \\
\text { to identify suitable methods to assess the progress of the developed strategy. } \\
\text { As there are numerous methods of evaluation, it is crucial that a suitable option } \\
\text { is used in context of the problem experienced in order to produce the best } \\
\text { possible feedback. } \\
\text { When an optimal evaluation method is applied, the findings will result in a clear } \\
\text { understanding of which development processes lead to discrepancies, } \\
\text { incongruities or failure to reach the intended outcome. }\end{array}$ & \\
\hline & 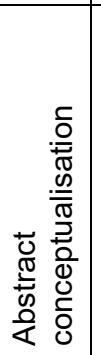 & $\begin{array}{l}\text { When a clear understanding can be achieved of which specific parts of the } \\
\text { collective whole were successful and unsuccessful the research process } \\
\text { naturally becomes easier to guide. } \\
\text { Targeted research can be conducted to find information that addresses the } \\
\text { discrepancies. All research previously undertaken can be reconsidered if there } \\
\text { is evidence that it can address the problem. } \\
\text { The objective is to refine specific elements of the developed strategy that were } \\
\text { identified as substandard, in order to improve the general success of the } \\
\text { strategy as a whole. }\end{array}$ & \\
\hline
\end{tabular}




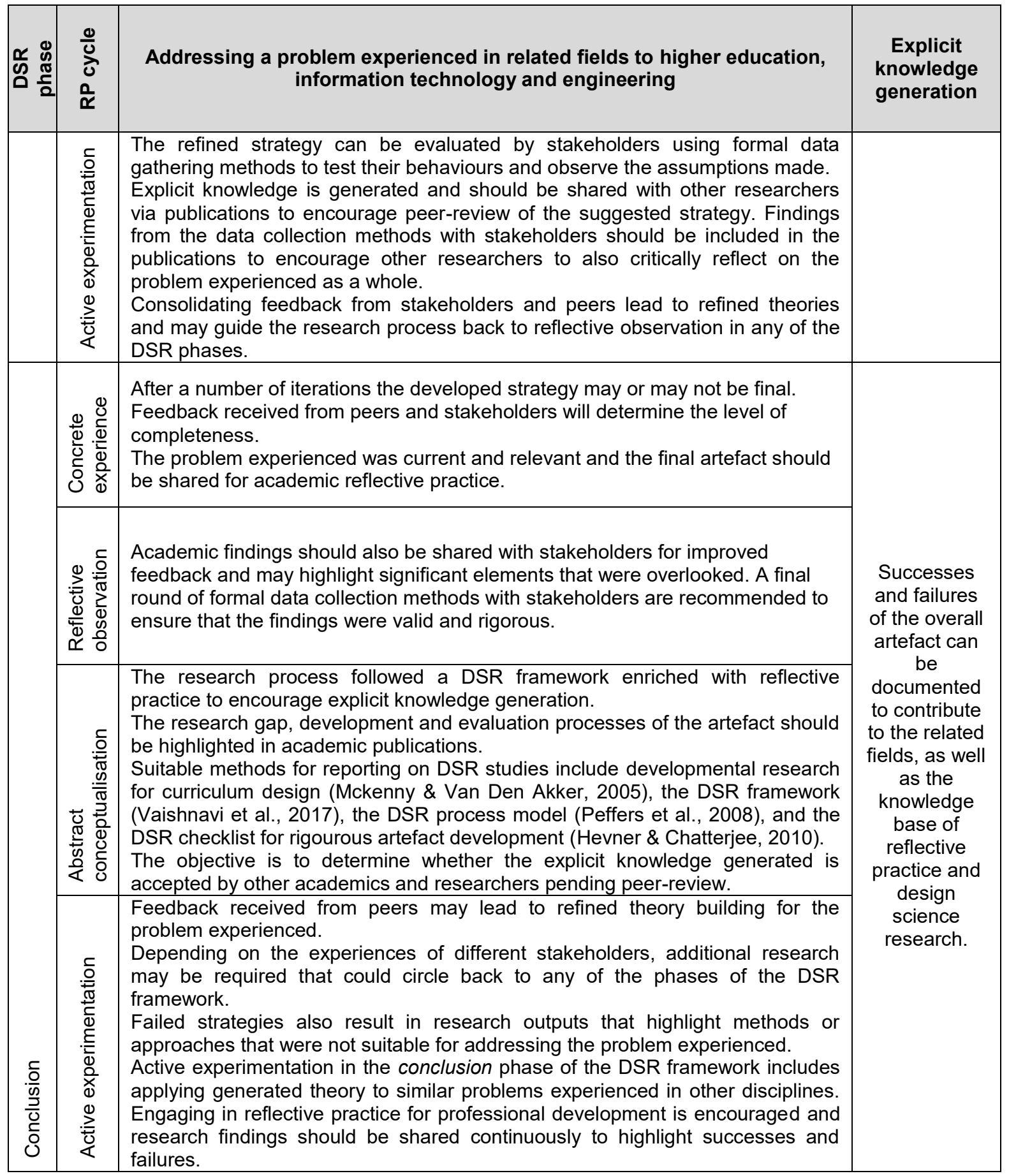

A demonstration of the application of embedding reflective practice in the DSR framework is explained in the next section.

\section{Demonstration}

The paper aims to improve knowledge generation in DSR through reflective practice. An example thereof is provided in context of the preparation of IT students for their chosen career.

There is an increasing concern that information technology (IT) graduates lack certain skills expected by industry when they enter the workforce.

Reflecting from a traditional DSR perspective, the researchers became aware of the problem and suggested a possible solution. An artefact in the form of guidelines for bridging the gap between IT theory at university 
level, and IT practice at industry level, could provide insight on improved practices. The process naturally lent itself to the phases of the DSR framework for artefact creation, and limitations in its knowledge generation process for the guidelines were identified. Following the original DSR framework resulted in guidelines that were only truly reflected on towards the end of the project. When the guidelines went through another iteration of application in context, more gaps were noted than guidelines originally produced. This led the researchers to believe that the DSR framework is a well-structured process for developing a prototype version of an artefact, but it lacks a scientific approach to knowledge management. The DSR framework is intended for experimental creation but does not explicitly indicate how to generate knowledge and how to retain and improve the knowledge generated before a project is concluded.

In order to provide some context for the demonstration, the following sections provide an overview of the research questions and objective, participants and data analysis methods used for the problem experienced.

\subsection{Research questions and objective}

In Table 2, during the first reflective practice cycle of the awareness of problem DSR phase, the initial problem experienced is described. From this experience, the following research questions were identified:

- Which industry related skills does an IT graduate need and typically lack?

- Can project-based learning be implemented in an IT degree to introduce industry-related IT skills?

- Can a set of guidelines be derived for bridging the IT theory-practice gap in order to improve the skills of IT graduates required by industry?

- How can reflective practice support the development of these guidelines (a design science research artefact) by generating explicit knowledge?

The primary objective of the research used in this demonstration was then to develop guidelines for bridging the gap between IT theory (standard IT teaching practices at university) and IT practice (the required industryrelated skills).

\subsection{Participants}

The central participants of the study were entry-level and exit-level students in their undergraduate IT degree. Other role players of the study included members from the IT industry and IT educators. The problem experienced started with exit-level IT students during 2017 when a skills gap was noticed between IT theory and IT practice. Industry was subsequently asked to provide feedback on skills IT graduates typically lack (Janse van Rensburg \& Goede, 2019). The research described in this demonstration is still ongoing at the time of this publication.

\subsection{Data analysis}

Qualitative methods were used to gather data from participants. Interpretive content analysis was used to analyse qualitative data in order to identify themes in the data. Findings from literature and identified themes were used to build guidelines for bridging the IT theory-practice gap.

Research conducted provided evidence on the validity of experiential learning through reflective practice with the focus on abstraction for improved knowledge generation. Following the process for reflective practice in the phases of the DSR framework added value to the knowledge generation process and resulted in guidelines for how to reflect-in-action, and reflect-on-action. Using the guidelines provided in Table 1 (and building on the model presented in Figure 5), Table 2 provides an overview of how reflective practice was embedded in the DSR framework in context of the problem experienced, resulting in guidelines for bridging the IT theorypractice gap. 
Table 2: A demonstration of reflective practice embedded in DSR to address a problem experienced

\begin{tabular}{|c|c|c|}
\hline 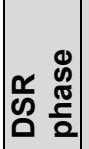 & $\begin{array}{l}\frac{0}{U} \\
\text { ত̀ } \\
\frac{0}{x}\end{array}$ & Problem in context \\
\hline 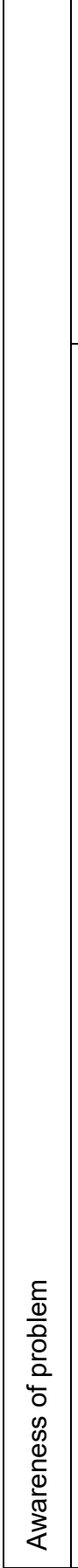 & 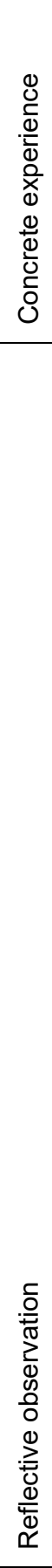 & 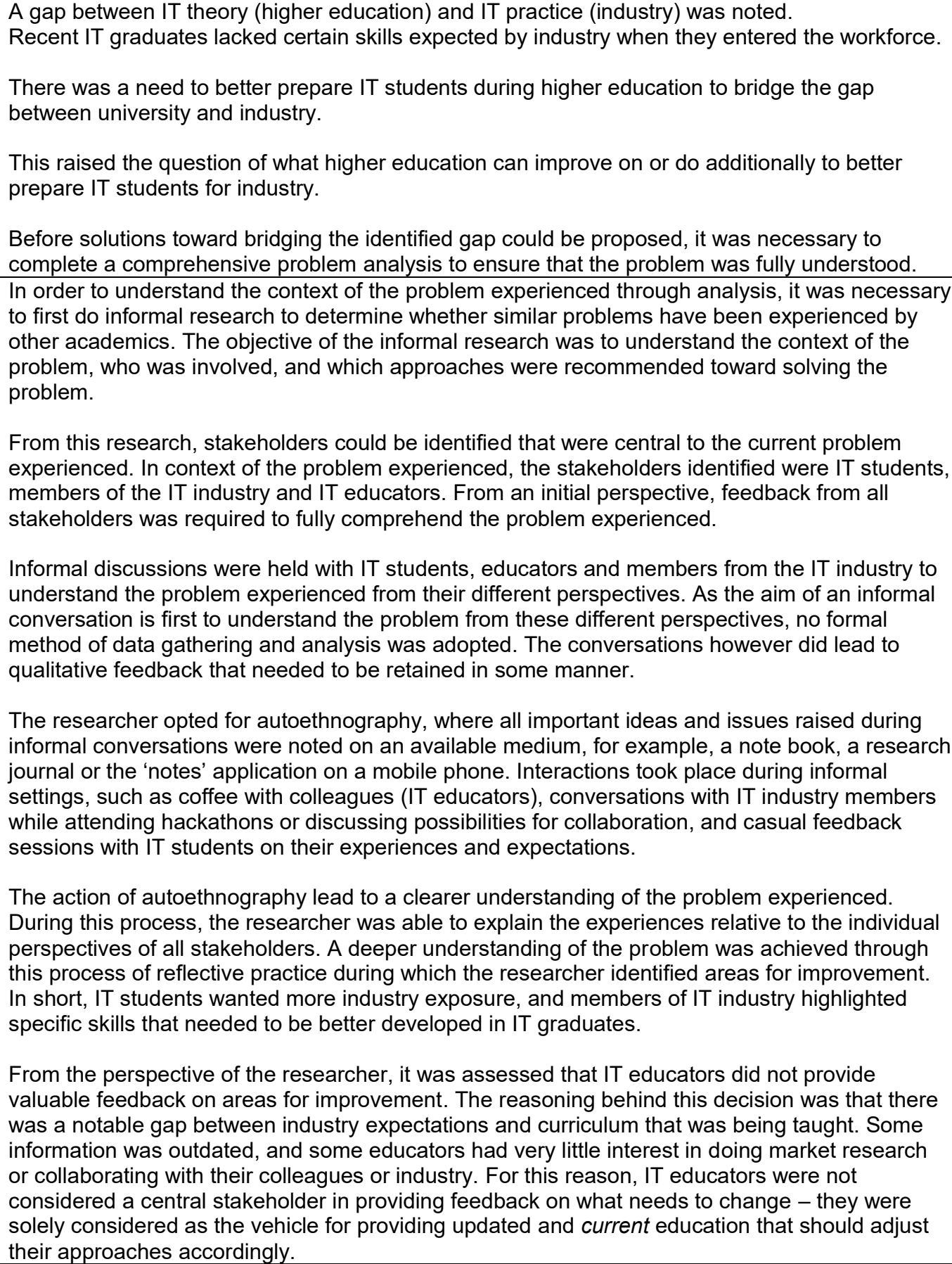 \\
\hline
\end{tabular}




\begin{tabular}{|c|c|c|}
\hline 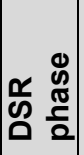 & & Problem in context \\
\hline & & $\begin{array}{l}\text { Having had a better understanding of the problem, the researcher was motivated to start looking } \\
\text { for information, theories or methods that could assist in addressing the problem experienced. } \\
\text { Existing strategies being used were reflected on, and notes were made regarding their } \\
\text { effectiveness toward supporting the feedback obtained (still via autoethnography). For example, } \\
\text { projects are often included in the assessments of IT students, but are most often compiled by the } \\
\text { IT educator. Through reflection and research, this approach could be improved on by managing } \\
\text { the scope of the project through the use of industry projects (rather than thumb-sucking the } \\
\text { scope), or topics that provide value and meaning to the student (i.e. community projects). } \\
\text { Before identifying any specific methods that could deliver a positive experience, new strategies } \\
\text { were also researched, reflecting on their appropriateness for the problem experienced and the } \\
\text { feedback obtained. Some of the strategies researched and reviewed in context of IT higher } \\
\text { education, for example, included problem-based learning, self-directed learning, blended } \\
\text { learning, computational thinking and project-based learning. }\end{array}$ \\
\hline & 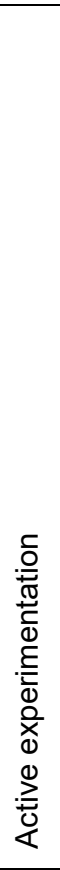 & $\begin{array}{l}\text { By identifying possible strategies from literature, the researcher could use these examples for } \\
\text { discussion with the relevant stakeholders. } \\
\text { Informal discussions with IT students and members from the IT industry were held to suggest the } \\
\text { strategies and their expectations thereof. Perceptions and opinions were still noted via } \\
\text { autoethnography methods. } \\
\text { Not all possible strategies were equally welcomed, but a general approval of project-based } \\
\text { learning (PBL) instruction was voiced. The reasoning behind this was that IT industry comprises } \\
\text { of project-based environments and research indicates that PBL settings promote the early } \\
\text { acquisition of diverse } 21^{\text {st }} \text { century competencies. Project-based learning also has the ability to } \\
\text { address the other approaches - as it can include methods for problem-based learning, self- } \\
\text { directed learning, blended learning, and improving computational thinking. } \\
\text { PBL was initially introduced in an exit-level IT module using industry scopes to understand } \\
\text { whether this approach would address the problem experienced. } \\
\text { The researcher wanted to understand why some methods were preferred as other proposed } \\
\text { approaches also had relevant advantages for the problem experienced. After additional research } \\
\text { was conducted, it was noted that the different approaches could still be used to achieve the } \\
\text { same goal. } \\
\text { This highlighted that the various teaching and learning approaches were not necessarily the } \\
\text { concern but rather how they were implemented. }\end{array}$ \\
\hline \multirow[b]{2}{*}{ 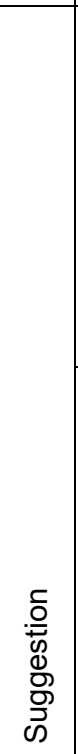 } & 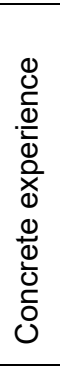 & $\begin{array}{l}\text { A lack of generic rules for the manner in which these approaches are implemented highlighted } \\
\text { the need for guidelines that indicate how these teaching and learning strategies, including PBL, } \\
\text { could be used to address skills shortages in IT students. } \\
\text { Guidelines were required that facilitate the manner in which these approaches should be } \\
\text { implemented so that they are industry focused and share the same goal - improving } 21^{\text {st }} \text { century } \\
\text { competencies. } \\
\text { Additional research was required before suggestions could be made to understand what the } \\
\text { contribution of the guidelines needed to be. }\end{array}$ \\
\hline & 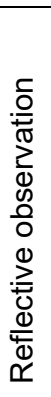 & $\begin{array}{l}\text { Research was conducted to find existing guidelines that can address the problem experienced. } \\
\text { The existing literature was critically reviewed to determine whether all suggested strategies, } \\
\text { including PBL instruction, were addressed by all existing guidelines. } \\
\text { The researcher continued to make notes on the qualitative data through autoethnography, } \\
\text { reviewing guidelines that were repeated, understanding why and how they were formulated, and } \\
\text { understanding the value and context of their application. } \\
\text { Appropriate guidelines found in existing literature were presented to students and industry during } \\
\text { informal discussions, and their perceptions and ideas were noted. }\end{array}$ \\
\hline
\end{tabular}




\begin{tabular}{|c|c|c|}
\hline 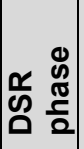 & $\begin{array}{l}\frac{0}{0} \\
\text { ত̃ } \\
\frac{0}{\alpha}\end{array}$ & Problem in context \\
\hline & 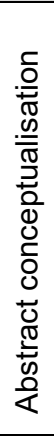 & $\begin{array}{l}\text { During the process of research and informal discussions, gaps in the existing guidelines were } \\
\text { identified. } \\
\text { Guidelines that were partially applicable were reconsidered and adjusted to better address the } \\
\text { problem experienced. } \\
\text { New techniques and processes in the form of guidelines needed to be developed to address the } \\
\text { missing information not covered in existing literature. } \\
\text { The objective was to consolidate existing guidelines with new suggested guidelines in order to } \\
\text { provide a single set of guidelines that can be followed to address the skills shortages and } \\
\text { improve } 21^{\text {st }} \text { century competencies of IT students. }\end{array}$ \\
\hline & 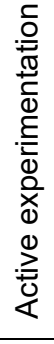 & $\begin{array}{l}\text { In order for the guidelines to be considered, they needed to be refined based on their acceptance } \\
\text { by the relevant stakeholders and their successful application in an IT curriculum. } \\
\text { Existing and suggested additional guidelines were proposed during informal discussions with } \\
\text { students and industry to determine whether they saturate the current need for skills development } \\
\text { to address } 21^{\text {st }} \text { century competencies. } \\
\text { Guidelines that were questioned were further refined, and an initial set of guidelines were } \\
\text { confirmed for implementation in a first instance of IT higher education. }\end{array}$ \\
\hline & 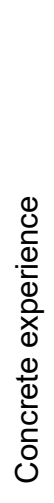 & $\begin{array}{l}\text { The problem experienced started with exit-level IT students, and the initial set of guidelines were } \\
\text { applied in context of their education. } \\
\text { The aim of applying the guidelines was to understand whether a positive experience in terms of } \\
\text { their career awareness and skills development could be achieved. } \\
\text { The guidelines were applied in context of relevant teaching and learning strategies such as PBL } \\
\text { to simulate an IT working environment which motivated their desire to learn. } \\
\text { While following the proposed guidelines it was noted that some guidelines did not have the } \\
\text { expected outcomes. } \\
\text { Additional research was required to understand why these guidelines did not have the intended } \\
\text { impact. }\end{array}$ \\
\hline 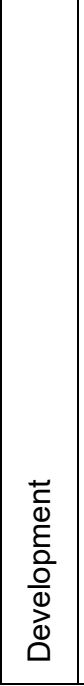 & 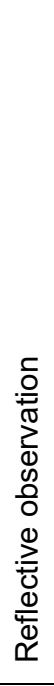 & $\begin{array}{l}\text { The researcher became aware that addressing these guidelines at exit-level of a curriculum is } \\
\text { too late in some instances to successfully prepare the soon to be IT graduate. } \\
\text { As the first research cycle where the guidelines were applied had started, it was necessary to } \\
\text { establish formal research methods for data gathering and analysis to address the problem } \\
\text { experienced. } \\
\text { The researcher asked IT students that formed part of an exit-level IT module in which the } \\
\text { guidelines were applied to complete an interpretive questionnaire. The feedback included their } \\
\text { perceptions of the strategy taken and provided suggestions to further improve the approaches } \\
\text { taken that did not meet their expectations. } \\
\text { The feedback was analysed in Atlas.ti using open coding to identify themes in the data. The } \\
\text { themes identified indicated advantages of the strategy taken, highlighted approaches that raised } \\
\text { career awareness and improved their } 21^{\text {st }} \text { century competencies, and provided additional } \\
\text { suggestions that they would find beneficial. } \\
\text { From the additional suggestions, it was realised that certain guidelines would have a greater } \\
\text { impact if they were applied earlier in the IT degree and not only at exit-level. }\end{array}$ \\
\hline
\end{tabular}




\begin{tabular}{|c|c|c|}
\hline 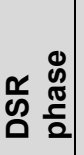 & $\begin{array}{l}\frac{0}{0} \\
\text { ত̀ } \\
0 \\
\alpha\end{array}$ & Problem in context \\
\hline & 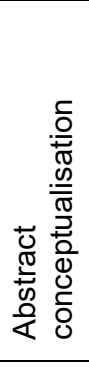 & $\begin{array}{l}\text { A conceptual framework was formed that following the guidelines at an earlier stage of the } \\
\text { curriculum can prepare the future IT graduate in a systematic manner. } \\
\text { Guidelines that were suitable to follow earlier in the IT degree needed to be identified. For } \\
\text { example, PBL instruction could also be implemented at IT extended level. } \\
\text { Additional guidelines were required that would suit the needs of the IT extended students. } \\
\text { The objective was to reflect on the initial set of guidelines and suggest improvements that would } \\
\text { assist the future IT graduates earlier in their degrees. }\end{array}$ \\
\hline & 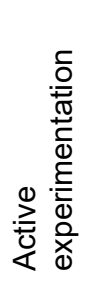 & $\begin{array}{l}\text { Guidelines that could be followed in an IT extended degree were identified and implemented at } \\
\text { entry-level of the curriculum. } \\
\text { The impact of the guidelines was informally observed and noted. } \\
\text { Certain guidelines were challenging to implement at entry-level and additional research was } \\
\text { required. }\end{array}$ \\
\hline & 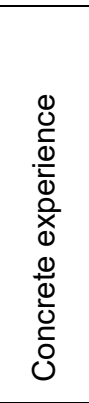 & $\begin{array}{l}\text { A problem was experienced when following the guidelines at entry-level of the curriculum. It was } \\
\text { noted that the guidelines cannot be applied in the exact same manner for entry- and exit-level IT } \\
\text { students. } \\
\text { For example, it is noted that the student groups require different motivation for completing } \\
\text { projects. Exit-level students were more focused on their careers and wanted to participate in } \\
\text { industry scope projects. Entry-level students were more focused on their studies, and engaged } \\
\text { better in projects that were relevant to their current context. } \\
\text { The researcher was cautious of adjusting guidelines without additional research and feedback to } \\
\text { better understand the problem experienced. }\end{array}$ \\
\hline & 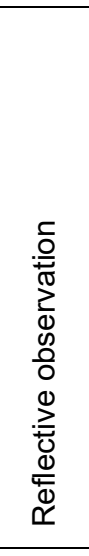 & $\begin{array}{l}\text { In order to understand the challenges experienced while implementing guidelines at entry-level } \\
\text { of the curriculum, IT extended students were asked to reflect on their experiences. } \\
\text { The data was gathered using guided reflective sheets that contained questions relating to their } \\
\text { experiences, preferred teaching and learning methods and self-reflection on improved } 21^{\text {st }} \\
\text { century competencies. } \\
\text { The feedback was analysed using a combination of basic descriptive statistics for the } \\
\text { quantitative data, as well as open coding for the qualitative data. } \\
\text { The aim was to understand why only certain approaches were successful following the initial set } \\
\text { of guidelines. } \\
\text { From the data analysis an understanding was achieved as to which approaches were valuable } \\
\text { and which approaches required further research and development. }\end{array}$ \\
\hline 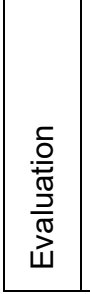 & 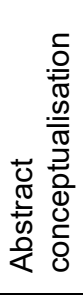 & $\begin{array}{l}\text { The approaches contained in guidelines that were found lacking needed further research for } \\
\text { possible solutions as to how they could be applied at different year levels. } \\
\text { The existing guidelines were evaluated to understand the extent of adjustments required so that } \\
\text { they would address the problem experienced. } \\
\text { The objective was to find strategies for applying similar guidelines at different year levels with the } \\
\text { common goal of improving the } 21^{\text {st }} \text { century skills of IT students. }\end{array}$ \\
\hline
\end{tabular}




\begin{tabular}{|c|c|c|}
\hline 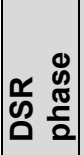 & $\begin{array}{l}\frac{0}{0} \\
﹎{0} \\
0 \\
\alpha\end{array}$ & Problem in context \\
\hline & 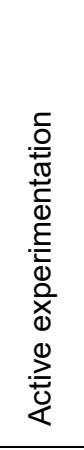 & $\begin{array}{l}\text { The appropriate guidelines were applied at entry-level and exit-level, but the scope was adjusted } \\
\text { to suit the context of the student. } \\
\text { When a new approach was implemented within a guideline, students were informed of how this } \\
\text { would improve their } 21^{\text {st }} \text { century competencies. } \\
\text { While the identified guidelines seemed to support the problem experienced, the scope was } \\
\text { continuously reevaluated and adjusted as necessary. } \\
\text { The learning process was continuous for entry-level and exit-level students, as well as the } \\
\text { researcher, who articulated her ideas noted through autoethnography via research publications } \\
\text { to share explicit knowledge on best practices using formal methods of data analysis. }\end{array}$ \\
\hline & 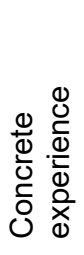 & $\begin{array}{l}\text { The set of guidelines were not finalised after a limited number of iterations had been concluded. } \\
\text { This implied that the guidelines should continuously be evaluated and reflected on for relevance } \\
\text { and applicability. } \\
\text { Where it was experienced that guidelines were not sufficient, more research was required in } \\
\text { order to attempt to saturate the information. }\end{array}$ \\
\hline & 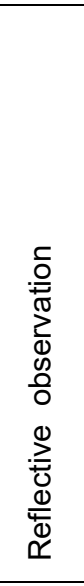 & $\begin{array}{l}\text { In order to understand whether the guidelines were sufficient, feedback was required from } \\
\text { members of the IT industry that had recently employed IT students that had been subject to the } \\
\text { guidelines. } \\
\text { Formal interviews were held with members from the IT industry, and the qualitative data was } \\
\text { analysed in Atlas.ti using open coding to identify themes in the data. } \\
\text { The objective of the data analysis was to determine whether members of industry could notice } \\
\text { improvements in the } 21^{\text {st }} \text { century competencies of IT students based on the initial feedback } \\
\text { received during informal conversations at the start of the research process. } \\
\text { Guidelines were discussed, and where additional concerns were voiced, supplementary research } \\
\text { was suggested to further understand the problem experienced. } \\
\text { At this stage of the research, it was important to publish research papers on the study to assist } \\
\text { with providing clarity on the problem experienced and addressing the gaps in literature. }\end{array}$ \\
\hline 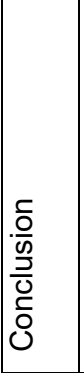 & 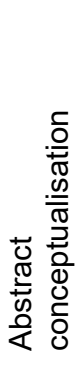 & $\begin{array}{l}\text { In the conclusion phase of the DSR framework, it is not only important to provide research } \\
\text { contributions on the literature gap identified, but also to report on the DSR process followed to } \\
\text { conduct the research. } \\
\text { The objective of this type of research publication is to provide explicit knowledge generated when } \\
\text { following a DSR framework or approach. } \\
\text { As the set of guidelines is also considered as an artefact that was created by following a DSR } \\
\text { approach, it was necessary to use a formal DSR reporting method such as the DSR checklist of } \\
\text { Hevner and Chatterjee (2010). }\end{array}$ \\
\hline
\end{tabular}




\begin{tabular}{|c|c|c|}
\hline 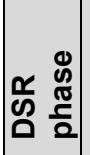 & 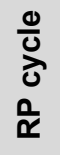 & Problem in context \\
\hline & 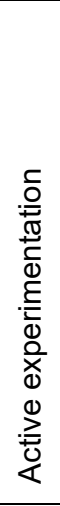 & $\begin{array}{l}\text { Preparing future IT graduates is an iterative and reflective process. As change occurs, guidelines } \\
\text { should be updated to remain current and relevant. } \\
\text { Guidelines should continuously be applied at all levels, contextual to the environment of the } \\
\text { student, to ensure a well-rounded work-ready student. } \\
\text { Reflective practice is central to the learning process of the student and the researcher, and } \\
\text { should continuously be implemented as part of the development process. } \\
\text { The DSR framework was enriched with reflective practice for explicit knowledge generation, and } \\
\text { in this example, resulted in the formulation of guidelines for bridging the IT theory-practice gap. } \\
\text { This method of explicit knowledge generation can also be applied in context of other disciplines } \\
\text { to structure the research in a professional and academic manner. }\end{array}$ \\
\hline
\end{tabular}

In the context of this example, explicit knowledge was generated in the following ways:

- Suitable strategies toward addressing the problem experienced was identified and highlighted in research publications.

- A gap in academic literature was identified for the creation of guidelines toward bridging the IT theory-practice gap.

- Through formal research of data gathering and analysis, specific strategies could be identified that would address the problem experienced and was highlighted in research publications.

- Through the process of development and iteration, shortcomings were identified in the strategies that could be refined for further research.

- Targeted evaluation methods that suited the development process of the problem experienced were highlighted in research publications.

- Results and findings from evaluation methods employed contributed to the academic knowledge base.

- Contributions to the knowledge base of design science research and reflective practice resulted in explicit discussions that address the problem experienced, while highlighting the elements of the research processes that were successful and unsuccessful.

\section{Summary}

The DSR framework is an excellent tool for prototyping artefact creation, but it is limited in its explicit methods for knowledge generation. When following the DSR framework, the researcher will iterate through the phases and produce an artefact that concluded as a prototype that addresses the current requirements of the problem. DSR more often results in outstanding artefacts, which can be implement and used for the specified problem, but that is not easily adaptable to a changing environment. In DSR, when the problem changes, a new artefact needs to be created and the DSR framework has to restart in the first phase. The goal-orientated nature of DSR is effective for immediate results, but not efficient in anticipating problems in a holistic manner.

Abstraction for tried and tested approaches is only reflected on in the concluding phase, which provides limited knowledge generation for the knowledge base of DSR. It is notable that following a DSR framework enriched with reflective practice results in a more rounded artefact, due to the reflective cycle that takes place between phases. The cyclical process of reflection allows the practitioner to address the current problem as well as anticipate and prepare for future variations of the problem. This allows the practitioner to holistically apply the DSR framework, and conclude the artefact without having to restart at phase one when problems are identified. This process of reflection results in improved knowledge generation for design science research.

\section{References}

Atkinson, S.P. \& Irving, J. 2013. Reflective practice: a non-negotiable requirement for an effective educator. London: College, B.U.

Boud, D., Keogh, R. and Walker, D. 1985. Reflection: Turning experience into learning, Kogan Page, London. 
Boyd, E.M. and Fales, A.W. 1983. Reflective learning: Key to learning from experience. Journal of humanistic psychology, Vol 23, No.2, pp.99-117.

Bratteteig, T. and Wagner, I., 2016. Unpacking the notion of participation in participatory design. Computer Supported Cooperative Work (CSCW), 25(6), pp.425-475.

Brown, T. and Wyatt, J., 2010. Design thinking for social innovation. Development Outreach, 12(1), pp.29-43.

Buckl, S., Ernst, A.M., Matthes, F., Ramacher, R. and Schweda, C.M., 2009, September. Using enterprise architecture management patterns to complement TOGAF. In 2009 IEEE International Enterprise Distributed Object Computing Conference (pp. 34-41). IEEE.

Donaldson, T. and Preston, L.E., 1995. The stakeholder theory of the corporation: Concepts, evidence, and implications. Academy of management Review, 20(1), pp.65-91.

Dunlap, J.C., 2006. Using guided reflective journaling activities to capture students' changing perceptions. TechTrends, 50(6), pp.20-26.

Ellis, C., Adams, T.E. and Bochner, A.P., 2011. Autoethnography: an overview. Historical Social Research/Historische Sozialforschung, pp.273-290.

Garrison, D.R., 1997. Self-directed learning: Toward a comprehensive model. Adult education quarterly, 48(1), pp.18-33.

Goertzel, B. and Wang, P., 2007. A foundational architecture for artificial general intelligence. Advances in artificial general intelligence: Concepts, architectures and algorithms, 6, p.36.

Gregor, S. and Hevner, A.R. 2013. Positioning and presenting design science research for maximum impact. MIS quarterly, Vol 37, No. 2,337-356.

Gregor, S. and Jones, D. 2007. The Anatomy of a Design Theory. Journal of the Association for Information Systems, Vol 8 , No. 5, Article 19.

Hevner, A. and Chatterjee, S. 2010. Design science research in information systems. Design science research in information systems: Integrated series in Information Systems, Vol 22, pp. 9-22.

Janse van Rensburg J.T., and Goede R. 2019. A Reflective Practice Approach for Supporting IT Skills Required by Industry Through Project-Based Learning. In: Kabanda S., Suleman H., Gruner S. (eds) ICT Education. SACLA 2018. Communications in Computer and Information Science, Vol 963, page 253 - 266. Springer, Cham.

Jarvis, J. 1992. Using diaries for teacher reflection on in-service courses. ELT journal, Vol 46, No. 2, pp.133-143.

Klein, H.K. and Myers, M.D. 1999. A set of principles for conducting and evaluating interpretive field studies in information systems. MIS quarterly, Vol 23, No.1, pp. 67-93.

Kolb, D.A. 1984. Experiential learning: Experience as the source of learning and development. Prentice-Hall, New Jersey.

Law, E.L.C. and Abrahão, S., 2014. Interplay between User Experience (UX) evaluation and system development.

Legris, P., Ingham, J. and Collerette, P. 2003. Why do people use information technology? A critical review of the technology acceptance model. Information \& management, 40(3), pp.191-204.

March, S. and Smith, G. 1995. Design and Natural Science Research on Information Technology. Decision Support Systems, Vol 15, No. 4, pp. 251-266.

Maruping, L.M., Venkatesh, V. and Agarwal, R., 2009. A control theory perspective on agile methodology use and changing user requirements. Information Systems Research, 20(3), pp.377-399.

Mezirow, J. 1981. A critical theory of adult learning and education. Adult Education, Vol 32, No. 2, pp. 3-24.

McKenney, S. and Van Den Akker, J. 2005. Computer-based support for curriculum designers: A case of developmental research. Educational Technology Research and Development, 53(2), pp.41-66.

Myers, M.D. 2009. Qualitative research in business and management, Sage Publications Ltd, London.

Oates, B.J. 2006. Researching information systems and computing, Sage, Los Angeles.

Osterman, K.F. 1998. Using Constructivism and Reflective Practice To Bridge the Theory-Practice Gap. Paper presented at the Annual Meeting of the American Educational Research Association, San Diego, CA. (ERIC Document Reproduction Service No. ED425518).

Osterman, K.F. and Kottkamp, R.B. 1993. Reflective practice for educators, Corwin Press, Newbury Park, CA.

Owen, C. 1997. Understanding Design Research. Toward an Achievement of Balance. Journal of the Japanese Society for the Science of Design, Vol 5, No. 2, pp. 36-45.

Peffers, K., Tuunanen, T., Rothenberger, M.A. and Chatterjee, S. 2008. A design science research methodology for information systems research. Journal of management information systems, Vol 24, No. 3, pp. 45-77.

Peirce, C.S. 1931-1935. Collected Papers of Charles Sanders Peirce, Harshorne, C. and Weiss, P. Eds. Vols. 1-6, Cambridge, MA: Harvard University Press.

Potts, C., Takahashi, K. and Anton, A.I. 1994. Inquiry-based requirements analysis. IEEE software, 11(2), pp.21-32.

Purao, S. 2002. Design Research in the Technology of Information Systems: Truth or Dare. Working Paper. GSU Department of CIS, Atlanta.

Purao, S. 2013. Truth or Dare: The Ontology Question in Design Science Research. Journal of Database Management, Vol 24, No. 3, pp. 51-66.

Schön, D.A. 1983. The reflective practitioner: How professionals think in action, Basic books, London.

Schön, D.A. 1987. Educating the reflective practitioner, Jossey-Bass, San Francisco.

Scotland, J. 2012. Exploring the philosophical underpinnings of research: relating ontology and epistemology to the methodology and methods of the scientific, interpretive, and critical research paradigms. English Language Teaching, Vol 5, No. 9, pp. 9-16.

Simon, H.A. 1996. The sciences of the artificial, 3rd Ed, MIT press, London. 
Takeda, H., Veerkamp, P., Tomiyama, T., and Yoshikawam, H. 1990. Modeling Design Processes. Al Magazine Winter, pp. 37-48.

Thomas, J.W. 2000. A review of research on project-based learning.

Ulrich, W., 1983. Critical heuristics of social planning: A new approach to practical philosophy.

Vaishnavi, V., Kuechler, W., and Petter, S. (Eds.). 2004/2017. Design Science Research in Information Systems. January 20, 2004 (created in 2004 and updated until 2015 by Vaishnavi, V. and Kuechler, W.); last updated (by Vaishnavi, V. and Petter, S.), December 20, 2017. URL: http://www.desrist.org/design-research-in-information-systems/

Walsham, G. 1993. Interpreting Information Systems in Organizations, Wiley, United Kingdom.

Wing, J.M., 2008. Computational thinking and thinking about computing. Philosophical Transactions of the Royal Society A: Mathematical, Physical and Engineering Sciences, 366(1881), pp.3717-3725.

Zalzal, V., Gava, R., Kelouwani, S. and Cohen, P. 2009. Acropolis: A fast prototyping robotic application. International Journal of Advanced Robotic Systems, 6(1), p.8.

Zeigler, B.P. and Mittal, S., 2005. October. Enhancing DoDAF with a DEVS-based system lifecycle development process. In 2005 IEEE international conference on systems, man and cybernetics, Vol. 4, pp. 3244-3251

Zhang, X., Kuchinke, L., Woud, M.L., Velten, J. and Margraf, J., 2017. Survey method matters: Online/offline questionnaires and face-to-face or telephone interviews differ. Computers in Human Behavior, 71, pp.172-180.

Zhang, Y. \& Wildemuth, B.M. 2009. Qualitative analysis of content. Applications of social research methods to questions in information and library science, 308:319. 